\title{
VIEWS OF UNIVERSITIES AND TERTIARY MATRICULATION EXAMINATION CANDIDATES (UTME) ON FACTORS AFFECTING THEIR CHOICE OF BUSINESS EDUCATION IN NIGERIA
}

\author{
ADAMU IBRAHIM AND MAGAJI, Z. B.
}

\begin{abstract}
This paper examines the perceived factors affecting the secondary school students' choice of Business Education in University and Tertiary Matriculation Examination (UTME) in Nigeria. The factors investigated are the profession, nomenclatures of the programme, parents, peer groups, mentors/role model, student's interest, job prospects and admission intricacy. The study had eight objectives and eight null hypotheses. The design used in the study was descriptive. The researchers distributed two hundred (200) copies of questionnaire to candidates registering for University and Tertiary Matriculation Examination in 2011/2012. Two rating scale structured questionnaire titled UTME Candidates and Business Education (UTMECBE) was the instrument used to gather data from the field for analysis. One hundred and eighty nine (189) copies of questionnaire were properly filled and subjected to statistical analysis using Statistical Package for Social Science version 16. Chi-square was used to test all the 8 null hypotheses at significance level of 0.05. The results show, among others that, teaching profession have significant effect on student's choice of Business Education at Universities and Tertiary Matriculation Examination in Nigeria. Based on this, the researcher recommended that government should organise public orientation programme to correct the misconception given to teaching profession (Business Education inclusive) as a programme meant for slow learners and misfits should be corrected.
\end{abstract}

Keywords: Business Education, University and Tertiary Matriculation Examination

\section{Introduction}

Business Education is a programme that facilitates the acquisition of practical and applied skills as well as basic knowledge. It is a planned programme of courses and learning experiences that explores the career options, supports basic academic and life skills needed for leadership, preparation for industry-defined work, academic and continuing education. The objectives of the programme is to equip graduates with skills needed for administrative cadre in government and in institution of higher learning and to provide students with skills and competence required for self-reliance and self-employment if the need arises. It was in keeping with the above tenet that Business Education was introduced into the national curriculum as reflected in the National Policy on education. With the release of the first edition of the National Policy on Education in 1977 (Federal Republic of Nigeria, 1977), the recognition placed on Business Education at tertiary institutions increased and more Polytechnics, Colleges of Education and Universities introduced Business Education programme (Ekpenyong \& Nwabuisi, 2003). With this development, institutions that introduced Business Education programme are directed by the Federal Government to phase out their business teachers programmes within the period of 1980-1990 with the singular objectives of providing secondary schools with qualified teachers. 
In the early seventies, Nigerian government influenced the admission standards by establishing the Joint Admission and Matriculation Board, JAMB, introducing Federal character, catchment areas, (Christopher 2009). Hence, to gain admission into Business Education programme, candidates must have the followings: (i) Credits in English language, Mathematics and any three relevant subjects such as Principles of Accounting, Commerce, Computer, Economics, Typing Office Practice; (ii) Sit and Pass the University Matriculation Examination which must include English, Mathematics and two other relevant subjects and; (iii) sit for Post-UTME examination and must have an aggregate average score determined by each university. The question now is that what factors determines students' choice of Business Education in their UTME? Bearing in mind that a choice of career by a student's tends to result in a happy, progressive and fulfilled life, conversely a wrong choice of career may destroy the future prospect of an individual, thus leading to unforgetable frustrations and woes. Scholars such as Kerka (2000), Bond McQuaid (2003) and Igbinedion (2011) noted that, career choice of secondary schools student is influenced by multiple factors. Kerka (2000), and Igbinedion (2011) argued that, personality, interests, self concept, cultural identity, globalization, socialization, role model, social support psychological, sociological, economic, situational, political and religious as significant influence on students choice of career. McQuaid and Bond (2003) maintained that, ethnic background, year in school, level of achievement, choice of subjects, attitudes and differences in job characteristics have influence on students future career decision. Hewitt (2010) identified that parent-child relationships have influence on child's career decision. He stressed that most students are influenced by careers that their parents favour and some choose to follow their passion regardless of how much or little it will make them while others choose the careers that give high income.

In the view of Hinchilife (1973) and Durojaiye (1970) friends and classmates are important factors in the career choice of adolescents. Owie (2003) advanced the position that the most important reason why a person chooses a particular career is that the person has intrinsic interest in the field. From the above, it could be noted that multiple factors influence the career choice of students; hence the researcher investigated the factors affecting choice Business Education among University and Tertiary Matriculation Examination (UTME) candidates in Nigeria.

\section{Statement of the Problem}

Despite the growing number of importance of Business Education and expanding educational programme in this area, many UTME candidates in Nigeria have been shunning selection of the programme and many are still questioning whether Business Education is worth selecting for admission. Most of UTME candidates see Business Education as a course of last, hence Business Education (secretarial education inclusive) records low enrolment and the few students enrolled do not seem to see much self worth in themselves (Igbinedion 2011). It is obvious that Business Education is usually not the first choice of study, and most students that secured admission in the area struggle for change of course as students view the profession with the mindset that it is education meant for the less privilege or a programme which upon graduation there is simply no opportunity for securing a job (Ohiwerei 2009). The stated problem triggered the researchers to investigate factors affecting the secondary 
school students choice of Business Education in University Matriculation Examination in Nigeria.

The study has the following objectives:-

1. Determine the effect of teaching profession on student's choice of choice Business Education in University and Tertiary Matriculation Examination (UTME).

2. Determine the effect of B.Ed nomenclature on student's choice of choice Business Education in University and Tertiary Matriculation Examination (UTME).

3. Determine the influence of parents on student's choice of choice Business Education at University and Tertiary Matriculation Examination (UTME).

4. Determine the extent peer groups affect student's choice of choice Business Education in University and Tertiary Matriculation Examination (UTME).

5. Determine the contribution of educational mentors on student's choice of choice Business Education in University and Tertiary Matriculation Examination (UTME).

6. Investigate the contribution of students' interest on their choice of Business Education in University and Tertiary Matriculation Examination (UTME).

7. Determine the effect future job prospects on students' choice Business Education in University and Tertiary Matriculation Examination (UTME).

8. Determine the effect of difficulties of admission on student's choice of choice Business Education in University and Tertiary Matriculation Examination (UTME).

\section{Null hypotheses}

The following hypotheses are raised and tested at significant level of 0.05

1. Teaching profession has no significant effect on student's choice of choice Business Education in University and Tertiary Matriculation Examination (UTME).

2. B.Ed nomenclature has no significant effect on student's choice of choice Business Education in University and Tertiary Matriculation Examination (UTME).

3. Parents have no significant effect on student's choice of choice Business Education in University and Tertiary Matriculation Examination (UTME).

4. Peer groups have no significant effect on student's choice of choice Business Education in University and Tertiary Matriculation Examination (UTME).

5. Educational mentors have no significant effect on student's choice of choice Business Education in University and Tertiary Matriculation Examination (UTME).

6. Students' interest has no significant effect on their choice of Business Education in University and Tertiary Matriculation Examination (UTME).

7. Future job prospects have no significant effect on students' choice Business Education in University and Tertiary Matriculation Examination (UTME).

8. Admission difficulties have no significant effect on student's choice of choice Business Education in University and Tertiary Matriculation Examination (UTME).

\section{Research Designs and Methodologies}

Survey design was adopted for the study. The researcher targeted 200 candidates who registered for University Matriculation Examination in 2011/2012. Multistage stratified random sampling design was used to select the sample based on their zones. Two rating 
scale structured questionnaire titled "UTME Candidates and Business Education" (UTMECBE) were used to collected data from the respondents. Thirty (30) copies of the instrument were given to UMTE candidates who were outside the study area for pilot study. The researchers used three days for the exercise. Copies of questionnaire retrieved were subjected to statistical analysis using Spilt-half method. The reliability coefficient of the instrument was 0.79 . This value shows that, the statements were consistent and measure the same construct. The questionnaire was validated by the experts of Business Education, sociology and psychology and education in Ahmadu Bello University, Zaria.

The instruments were delivered to target respondents in business centers where UTME candidates do their online registration. The candidates were instructed to fill the instrument and returned next day. Data was collected with the help of the operator of cyber-café. 186 copies of questionnaire retrieved were analyzed with the help of "SPSS" using chi-square statistics to test the null hypotheses and output presented in this report is in Tables. All the hypotheses were tested at significance level of 0.05 .

\section{Results of the Study}

Analyses of data used to test the 8 null hypotheses are as presented in Table 1 to 8.

$\mathrm{H}_{\mathrm{O} 1}$ : Teaching profession has no significant effect on student's choice of choice Business Education in University and Tertiary Matriculation Examination (UTME).

Result of data used to test null hypothesis one is presented in Table 1

Table 1: Chi-square Computation for Hypothesis 1: Effect of teaching profession on students choice of Business Education in UTME

\begin{tabular}{llllll}
\hline Response & $\begin{array}{l}\text { Observed } \\
\text { frequency }\end{array}$ & $\begin{array}{l}\text { Expected } \\
\text { frequency }\end{array}$ & fo-fe & $(\mathrm{fo}-\mathrm{fe})^{2}$ & $\underline{(\mathrm{fo}-\mathrm{fe})^{2}} \div \mathrm{Fe}$ \\
\hline Yes & 169 & 94.5 & 74.5 & 5550.25 & 58.73 \\
No & 20 & 94.5 & -74.5 & 5550.25 & 58.73 \\
\hline Total & 189 & 189 & 0 & 11100.5 & 117.46 \\
\hline
\end{tabular}

Analysis of data collected in respect of null hypothesis one shows that $\chi^{2}$ cal is greater than $\chi_{\text {tab }}^{2}(117.46$ is greater than 3.841). The null hypothesis is therefore rejected. The result therefore indicates that, teaching profession has significant effect on student's choice of choice Business Education in University and Tertiary Matriculation Examination (UTME).

$\mathrm{H}_{\mathrm{O} 2}$ : B.Ed. nomenclature has no significant effect on student's choice of choice Business Education in University and Tertiary Matriculation Examination (UTME). 
Table 2: $\quad$ Chi-square Computation for Hypothesis 2: Effect of B.Ed. nomenclatures on students choice of Business Education in UTME

\begin{tabular}{llllll}
\hline Response & $\begin{array}{l}\text { Observed } \\
\text { frequency }\end{array}$ & $\begin{array}{l}\text { Expected } \\
\text { frequency }\end{array}$ & fo-fe & (fo-fe $)^{2}$ & ${\text { (fo-fe })^{2}}^{2} \div \mathrm{Fe}$ \\
\hline Yes & 143 & 94.5 & 48.5 & 2352.25 & 24.89 \\
No & 46 & 94.5 & -48.5 & 2352.27 & 24.89 \\
\hline Total & 186 & 189 & 0 & 4704.5 & 49.78 \\
\hline
\end{tabular}

Table 2 present the analysis of data used to test null hypothesis two. From the Table, the calculated $\chi_{\text {cal }}^{2} 49.78$ is greater than $\chi_{\text {tab }}^{2} 3.841$. The analysis therefore indicates that nomenclatures have significant effect on student's choice of Business Education in University in Tertiary Matriculation Examination (UTME). The null hypothesis is therefore rejected.

Ho3: Parents have no significant effect on student's choice of choice Business Education in University and Tertiary Matriculation Examination (UTME).

Table 3: Chi-square Computation for Hypothesis 3: Effect of Parents on students' choice of Business Education in UTME

\begin{tabular}{llllll}
\hline Response & $\begin{array}{l}\text { Observed } \\
\text { frequency }\end{array}$ & $\begin{array}{l}\text { Expected } \\
\text { frequency }\end{array}$ & fo-fe & $(\text { fo-fe })^{2}$ & ${\text { (fo-fe })^{2}}^{2}-\mathrm{Fe}$ \\
\hline Yes & 144 & 94.5 & 49.5 & 2450.25 & 25.93 \\
No & 45 & 94.5 & -49.5 & 2450.25 & 25.93 \\
\hline Total & 189 & 189 & 0 & 4900.5 & 51.86 \\
\hline
\end{tabular}

Result used to test null hypothesis three revealed $\chi_{\text {cal }}^{2}>\chi_{\text {tab }}^{2}(51.85$ is greater than 3.841$)$. The analysis shows that Parents have significant effect on student's choice Business Education in University and Tertiary Matriculation Examination (UTME). Hence the null hypothesis is therefore not retained.

HO4$_{\text {O4 }}$ Peer groups have no significant effect on student's choice of choice Business Education in University and Tertiary Matriculation Examination (UTME).

Table 4: Chi-square Computation for Hypothesis 4: Effect of Peer groups on students' choice of Business Education in UTME

\begin{tabular}{llllll}
\hline Response & $\begin{array}{l}\text { Observed } \\
\text { frequency }\end{array}$ & $\begin{array}{l}\text { Expected } \\
\text { frequency }\end{array}$ & fo-fe & $(\mathrm{fo}-\mathrm{fe})^{2}$ & ${\text { (fo-fe })^{2}}^{2} \div \mathrm{Fe}$ \\
\hline Yes & 152 & 94.5 & 57.5 & 3306.25 & 34.99 \\
No & 37 & 94.5 & -57.5 & 3306.25 & 34.99 \\
\hline Total & 189 & 189 & 0 & 6612.5 & 69.98 \\
\hline
\end{tabular}

Result of Chi-square analysis used test null hypothesis four shows the calculated value of 34.99 which is greater than the Table value of $3.481\left(\chi_{\text {cal }}^{2} 69.98>\chi_{\text {tab }}^{2} 3.841\right)$. The test therefore shows that peer groups have significant effect on student's of choice Business Education in University and Tertiary Matriculation Examination (UTME). The null hypothesis is therefore rejected. 
Views of Universities and Tertiary Matriculation Examination Candidates (UTME) on Factors Affecting their Choice of Business Education in Nigeria

$\mathrm{H}_{\mathrm{O5}}$ : Educational mentors have no significant effect on student's choice of choice Business Education in University and Tertiary Matriculation Examination (UTME).

Table 5: Chi-square Computation for Hypothesis 5: Effect of Educational mentor/role model on students choice of Business Education in UTME

\begin{tabular}{llllll}
\hline Response & $\begin{array}{l}\text { Observed } \\
\text { frequency }\end{array}$ & $\begin{array}{l}\text { Expected } \\
\text { frequency }\end{array}$ & fo-fe & $(\text { fo-fe })^{2}$ & ${\text { (fo-fe })^{2} \div \mathrm{Fe}}$ \\
\hline Yes & 144 & 94.5 & 49.5 & 2450.25 & 25.93 \\
No & 45 & 94.5 & -49.5 & 2450.25 & 25.93 \\
\hline Total & 189 & 189 & 0 & 4900.50 & 51.86 \\
\hline
\end{tabular}

Analysis of respondent's opinion used to test null hypothesis 5 shows Chi-square value of 51.86 against the Table value of 3.841. $\left\{\left(\chi_{\text {cal }}^{2}(51.86)>\chi_{\text {tab }}^{2}(3.841)\right\}\right.$. The null hypothesis is therefore rejected. It indicates therefore, that students educational mentors has no significant effect on their choice of Business Education in University and Tertiary Matriculation Examination (UTME).

H06: Students' interest has no significant effect on their choice of Business Education at University and Tertiary Matriculation Examination (UTME).

Table 6: Chi-square Computation for Hypothesis 61: Effect of students interest on choice of Business Education in UTME

\begin{tabular}{llllll}
\hline Response & $\begin{array}{l}\text { Observed } \\
\text { frequency }\end{array}$ & $\begin{array}{l}\text { Expected } \\
\text { frequency }\end{array}$ & fo-fe & $(\text { fo-fe })^{2}$ & ${\text { (fo-fe })^{2} \div \mathrm{Fe}}$ \\
\hline Yes & 110 & 94.5 & 15.5 & 240.25 & 2.54 \\
No & 79 & 94.5 & -15.5 & 240.25 & 2.54 \\
\hline Total & 189 & 189 & 0 & 480.5 & 5.08 \\
\hline
\end{tabular}

The result of students views presented in Table 5 shows that calculated $\chi_{\text {cal }}^{2} 5.08$ is greater

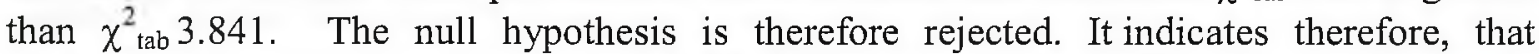
student's interest has significant effect on their choice of Business Education in University and Tertiary Matriculation Examination (UTME).

$\mathrm{H}_{07}$ : Future job prospects have no significant effect on students' choice Business Education in University and Tertiary Matriculation Examination (UTME).

Table 7: Chi-square Computation for Hypothesis 7: Effect of Future Job Prospects on students choice of Business Education in UTME

\begin{tabular}{llllll}
\hline Response & $\begin{array}{l}\text { Observed } \\
\text { frequency }\end{array}$ & $\begin{array}{l}\text { Expected } \\
\text { frequency }\end{array}$ & fo-fe & $(\text { fo-fe })^{2}$ & $\underline{\text { fo-fe }^{2}} \div \mathrm{Fe}$ \\
\hline Yes & 95 & 94.5 & 0.5 & 0.25 & 0.003 \\
No & 94 & 94.5 & -0.5 & 0.25 & 0.003 \\
\hline Total & 189 & 189 & 0 & 0.50 & 0.006 \\
\hline
\end{tabular}


Table 7 above shows that calculated $\chi_{\text {cal }}^{2} 0.006$ is less than $\chi_{\text {tab }}^{2} 3.841$. The analysis therefore shows that job prospects have no effect on the choice of Business Education among UTME canldidates in Nigeria. The null hypothesis is therefore retained.

$\mathrm{H}_{\mathrm{O8}}$ : Admission difficulties have no significant effect on student's choice of choice Business Education in University and Tertiary Matriculation Examination (UTME).

Table 8: Chi-square Computation for Hypothesis 8: Effect of Admission Intricacy on Students choice of Business Education in UTME

\begin{tabular}{|c|c|c|c|c|c|}
\hline Response & $\begin{array}{l}\text { Observed } \\
\text { frequency }\end{array}$ & $\begin{array}{l}\text { Expected } \\
\text { frequency }\end{array}$ & fo-fe & $(\mathrm{fo}-\mathrm{fe})^{2}$ & $(\text { fo-fe })^{2} \div \mathrm{Fe}$ \\
\hline Yes & 99 & 94.5 & 4.5 & 20.25 & 0.21 \\
\hline $\mathrm{No}$ & 90 & 94.5 & -4.5 & 20.25 & 0.21 \\
\hline Total & 189 & 189 & 0 & 41 & 0.42 \\
\hline
\end{tabular}

The analysis of data in Table 8 was used to test null hypothesis 8 . From the Table, the calculated $\chi_{\text {cal }}^{2}<\chi_{\text {tab }}^{2}(0.42<3.841)$. The result shows indicated admission intricacy has no significant effect on students' choice of Business Education in University and Tertiary Matriculation Examination (UTME).

\section{Discussions of the Findings}

The purpose of this study was to examine the factors affecting their choice Business Education in UTME. The study revealed that:-

Test of null hypothesis indicates that teaching profession affects the choice of choice Business Education among at University and Tertiary Matriculation Examination (UTME). The finding of this study further affirmed that of Myburgh (2005) that reports that, discrimination in certain professions such as teaching prevent students from choosing the careers. This tends to corroborate an earlier study of Hargreaves, Cunninghman, Hansen, McLintyre \& Oliver (2007). They opined that teaching is persistently perceived as a less rewarding profession, the author stressed that, this affects their children interest in the profession. Lawal (2012) further affirmed that parents who are in a better position to positively project teaching as a profession have probably looked down on teachers and the teaching profession, hence affecting their children from choose the career at university level.

The study further revealed that the nomenclatures (B.Ed or B.Sc Ed) affected the choice of choice of Business Education among at University and Tertiary Matriculation Examination (UTME). The result of the finding is in line with that of Bandura, Barbaranelli, Caprara, \& Pastorelli (2001) who states that each individual undertaking the process is influenced by several factors including the context in which they live in, their personal aptitudes, social contacts and classification of future educational attainment. Students' perception of being suitable for particular jobs also has been found to be influenced by a number of factors including e differences in job characteristics and nomenclatures (McQuaid and Bond, 2003).

The study further revealed that the wish of parents affects the choice of Business Education among secondary school students sitting for UTME. The finding concurred with that of them 
Taylor, Harris, and Taylor (2004) who reported that parental support and encouragement are important factors that have been found to influence career choice. Children may choose what their parents desire simply to please them. Accordingly, scholarship such as Kenny, Blustein, Chaves, Grossman, and Gallagher (2003); Chaves, Diemer, Blustein, Gallagher, DeVoy, Casares, and Perry (2004) \& Constantine, Wallace, and Kindaichi (2005) reported that parental support upon school children determines their career choice. The study of Hewitt (2010) also indicates that career choice of most students are influenced by careers that their parents favour, others follow the careers that their educational choices have opened for them, some choose to follow their passion regardless of how much or little it will make them while others choose the careers that give high income. Alavi, Rahim and Abd (2013) reported that the negative image remained resilient among parents and teachers, especially in deciding on career paths in technical and vocational (Business Education inclusive) fields.

Test of null hypothesis four shows that the influence of peer groups affects the choice of Business Education among students that are sitting for UTME in Nigeria. The study of Hinchilife (1973) and Duroyaiye (1970) earlier shows that studies that friends weigh heavily with some students, and that friends are an important factor in the career choice of adolescents. Natalie (2006) further affirmed that through interaction with the context of peer learn about and explore careers which ultimately lead to their career choice. Pummel, Harwood and Lavallee (2008) reports that external influences that help to shape an individual's career choice are also influenced by significant others through social support from peers. Arudo (2008) reported that most students are left in the hands of their fellow peers to offer the necessary guidance.

The study also revealed that educational mentors/role model of students affect students choice of Business Education in UTME. In a study by Perrone et al., (2001) on role model influence on the career decisiveness of college students, it was found that role model supportiveness, and quality of relationship contributed to the career choice of students.

Furthermore the study shows that student's interest has effect on choice of Business Education among secondary school students in UTME. The outcome of the study agreed with that of Owie (2003) advanced the position that the most important reason why a person chooses a particular career is that the person has intrinsic interest in the field. Dediemko (2005) and Perrone, et al., (2001) also reported that students' interests provide the main motives for their career choice. This results show that when choosing careers most students consider their interests.

The finding of this study revealed that Job prospects have no effect on student's choice of Business Education in UTME. The finding differ from those of Myburgh (2005) which shows availability of employment as the most influential factor in students' career choices. Dlamini (2004) and Stebleton (2007) also reported economic reasons as the most influential factors when it comes to career choice.

\section{Conclusion}

Based on the findings of the study, the researcher concluded that: 
i. Teaching profession in Nigeria continues to enjoy low esteem, as a result, this discourage candidates from choosing it in UTME. Those that even choose it in - UTME, consider it as a last resort.

ii. UTME candidates are aware that admission into Business Education is open to all and they are aware of the job opportunities upon graduation

iii. Despite that admission into business education programme is open and availability of prospects upon graduation, parents, peer groups, mentor/role model seem not to have interest in the programme. This will affect students passionate of the programme.

\section{Recommendations}

Based on the findings of this study, it is hereby recommended that:

1. Government should organise public orientation programme to correct the misconception given to teaching profession (Business Education inclusive) as a programme meant for slow leamers and misfits should be corrected;

2. Parents should encourage their children to develop interest in Business Education programme and at the same time provide them with the enabling support to that will encourage them;

3. Government should provide fund and equipment for the smooth running of Business Education programmes as this will encourage parents, teachers and students;

4. Guidance and counselling unit in secondary schools should organised mass enlightenment programmes. This will help to change the negative perceptions students have on Business Education and; 


\section{References}

Arudo, T. O. (2008). Peer counseling experience among selected Kenyan secondary schools. KAPC Conference, 2nd - 4th September. From http://www.kapc.or.ke/downloads/Arudo. retrieved on 24th September, 2013

Bandura A., Barbaranelli C. ; Caprara, G. V. \& Pastorelli, C. (2001). Self-efficacy beliefs as shapers of children's aspirations and career trajectories. Child Development, 72: 187-206. Retrieved from http://www.uky.edu/ eushe2/Pajares/ParentalSE.pdf

Bishop, J. H., \& Mane, F. (2004). The impacts of career-technical education on high school labor market success. Economics of Education Review, 23(4): 381-402.

Chaves, A. P.; Diemer, M. A.; Blustein, D. L.; Gallagher, L. A.; DeVoy, J. E.; Casares, M.T. $\&$ Perry, J.C. (2004). Conceptions of work: The view from urban youth. Journal of Counseling Psychology, 51(3): 275-286.

Christopher O. (2009). The State Of Higher Education in Nigeria. From mailto:Yemison2@aol.com. Retrieved on 22/4/2012

Constantine, M.G.; Wallace, B.C. \& Kindaichi, M.M. (2005). Examining contextual factors in the career decision status of African American Adolescents. Journal of Career Assessment, 13 (3): 307-319.

Dlamini, M. P., Ngenya, S. S. \& Dlamini, B. M. (2004). Reasons girls choose agriculture or other science and technology programmes in Swaziland. Journal of International Agricultural and Extension Education, 11(3): 69-77.

Durojaiye, M. O. (1970). School education and occupational choice: Social psychology research in a Nigerian International Secondary School, West African Journal of Education. 2: 79-84.

Ekpenyong E. E. \& Nwabuisi J. (2003). Business Teacher Education in Nigeria. Projecting a New Direction. Journal of Vocational Education and Training, 55(1): 33-46.

Federal Rep. of Nigeria (1977). National Policy on Education Lagos: Federal Ministry of Education.

Hairston, J. E. (2000). "How Parents Influence African American Students decision to Prepare for Vocational Teaching Career". Journal of career and Technical Education, 16(2): 1-15.

Hargreaves, L., Cunninghman, M., Hansen, A., McLintyre, D. and Oliver, C. (2007). The Status of Teachers and the Teaching Profession in England. London: Department for Education Skills.

Hewitt, J. (2010). Factors influencing career choice. Cited from www.ehow.com on $25 / 08 / 2012$ 
Hinchlife, K. (1973). Manpower planning and occupational choice in Nigeria. West African Journal of Education. 18: 1-10.

Igbinedion, V. I. (2011). Perception of Factors that Influence Students' Vocational Choice of Secretarial Studies in Tertiary Institutions in Edo State of Nigeria. European Journal of Educational Studies, 3(2): 338-352. Retrieved from http://www.uniben.edu/sites

Kenny, M. E., Blustein, D. L., Chaves, A., Grossman, J. M. \& Gallagher, L. A. (2003). The role of perceived barriers and relational support in the educational and vocational lives of urban high school students. Journal of Counseling Psychology, 50(2): 142-155.

Kerka, S. (2000). Career development, gender, race and class. ERIC Clearing house on Adult Careed and Vocational Education Columbus. ED 421641.

Khadijah Alavi K.; Rahim M. S. \& Abd, H. (2013). Image of Technical Education and Vocational Training from the Perspective of Parents and Teachers. Journal of Technical Education and Training, 5 (1). From http://penerbit.uthm.edu.my/. Retrieved on $30 / 10 / 2013$

Lawal B. O. (2012). Analysis of Parents, Teachers and Students' Perception of Teaching Profession in South-West Nigeria. Asian Social Science, 8 (1): 119 - 124. From http://dx.doi.org/10.5539/. Retrieved on 30/9/2013.

McQuaid, R. \& Bond, S. (2003). Gender stereotyping of career choice. Retrieved from http://www.careers-scotland.org.uk 13.07.2013.

Myburgh, J. E. (2005). An empirical analysis of career choice factors influencing first year accounting students at the University of Pretoria. Meditari Accounting Research Journal, 13 (2): 35-48.

Natalie, M. F. (2006). Factors influencing career choice of adolescents and young adults in rural Penn Sylvia. Journal of Extension, 44 (3): Retrieved from http://www.joe.org/ioe/

Ohiwerei F. O. (2009). Job Prospect for Business Educators University Graduates in Nigeria. Current Research Journal of Social Sciences, 1(3): 70-73. Retrieved from http://maxwellsci.com/print/criss/

Owie, I. (2003). Teaching, apriori or aposteriori decision: A preliminary analysis of effective impact, African Journal of Studies in Education, 1 (1): 21-29.

Perrone, K. M.; Sedlacek, E. W. and Alexander, M. C. (2001). Gender and ethnic differences In career goal attainment.Career Development Quarterly. 50 (2): 168-178.

Pummel, B.; Harwood, C. \& Lavallee, D. (2008). Jumping to the next level: A qualitative examination of within career transition in adolescent's event riders, Psychology of Sport and exercise. 9(4): 427-447.

Stebleton, M. J. (2007) Career counseling with African immigrant colleges: theoretical approaches and implications for practice. Career Development Quarterly, 55 (4): 290-312. 
Taylor, J.; Harris, M. \& Taylor, S. (2004). Parents have their say about their college aged children's career decisions. National Association of Colleges and Employers Journal, 64 (3). 